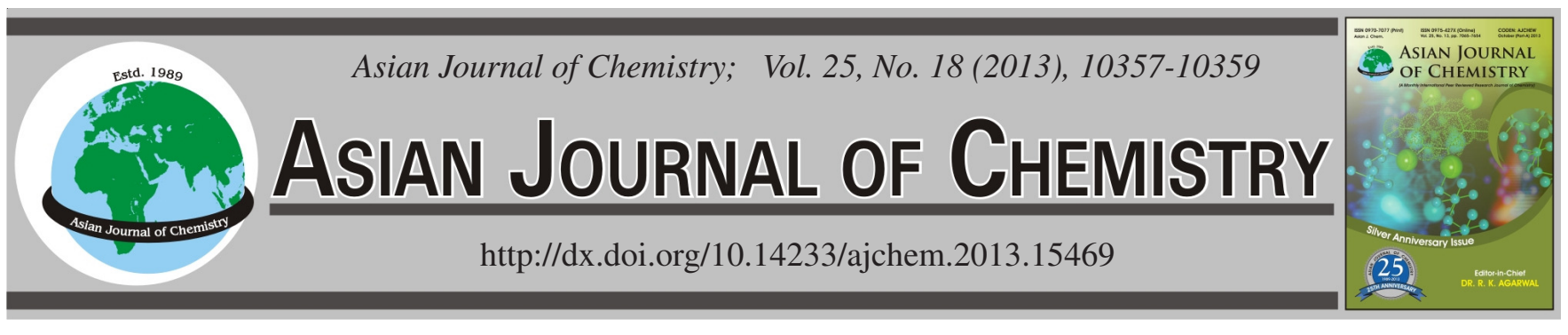

\title{
Synthesis and Theoretical Studies of Methyl 2-[(2-oxo-2H-chromen-4-yl)oxy]acetate
}

Ahmed A. Al-Amiery ${ }^{1,2, *}$, Hasan R. Obayes ${ }^{1}$, Ghadah H. Alwan ${ }^{3}$, Abdul Amir H. Kadhum ${ }^{2}$ and Abu Bakar Mohamad ${ }^{2}$

${ }^{1}$ Applied Chemistry Division, Applied Science Department, University of Technology, Baghdad 10001, Iraq ${ }^{2}$ Department of Chemical \& Process Engineering, Universiti of Kebangsaan Malaysia, Bangi, Selangor 43000, Malaysia

${ }^{3}$ Industrial Application Center, Industrial Research and Development Directorate, Ministry of Science and Technology, Baghdad, Iraq

*Corresponding author: E-mail: dr.ahmed1975@gmail.com

A derivative of 4-hydroxycoumarin, namely, methyl 2-[(2-oxo- $2 H$-chromen-4-yl)oxy]acetate was synthesized and characterized by means of it UV-visible, FT-IR, ${ }^{1} \mathrm{H}-\mathrm{NMR}$ and ${ }^{13} \mathrm{C}$-NMR spectral data. Research has included finding the best method of calculation to six kinds of stretching vibration frequencies contained within the molecule \{methyl 2-[(2-oxo-2H-chromen-4-yl)oxy]acetate . Chosen four DFT models are given by combining the exchange and correlation functional and four basis set to get sixteen different method of calculating. It is found that the best method of calculation to frequency of stretching vibration for $(\mathrm{C}-\mathrm{H})$ bond is (HCTH/DGTZVP), for frequency of stretching vibration for $(\mathrm{C}=\mathrm{O}$, ester) bond is (MPW1PW91/LanL2DZ), for frequency of stretching vibration for $(\mathrm{C}=\mathrm{O}$, lactone) bond is (HCTH/LanL2DZ), for frequency of stretching vibration for $(\mathrm{C}=\mathrm{C})$ bond is $(\mathrm{B} 3 \mathrm{LYP} / \mathrm{DGTZVP})$. While calculations showed that the method (HCTH/DGTZVP) needs time more than the rest of the calculation methods.

Key Words: 4-hydroxycoumarin, DFT, B3LYB, LUMO, HMOM.

\section{INTRODUCTION}

Coumarin and its derivatives have received considerable attention in the past few years not only for their versatile biological and medical properties ${ }^{1}$, such as anticoagulant, estrogenic, dermal photosensitizing, antimicrobial, vasodilator, molluscicidal, antihelmintic, sedative and hypnotic, analgesic and hypothermic actions ${ }^{2-13}$. Coumarin derivatives exhibit not only excellent biological and medical activities ${ }^{14}$, but also have the superior thermal stability and outstanding optical properties, including extended spectral responses, high quantum yields and superior photostability. Optical applications of these compounds, such as laser dyes, nonlinear optical chromophore, fluorescent whiteners, fluorescent probes, polymer science, optical recording and solar energy collectors, have been widely investigated ${ }^{15-20}$. More importantly, coumarin dyes are used as blue, green and red dopants in organic light-emitting diodes $(\mathrm{OLEDs})^{21,22}$. The vibrational spectroscopic techniques (IR and Raman spectroscopy) are powerful molecular structural techniques for the investigation of biological systems. IR and Raman spectroscopy are noninvasive methods yielding molecular fingerprint information and thus, allowing a fast and reliable analysis of complex biological systems such as bacterial or yeast cells ${ }^{23}$.

In the present work, geometric and vibrational properties of methyl 2-[(2-oxo-2H-chromen-4-yl)oxy]acetate, mentioned above. the IR spectrum of this molecule is recorded and the complete assignment is provided for the first time, to the best of our knowledge. We applied the DFT method to study the IR spectroscopic properties of target molecule and combining the exchange and correlation functional for four basis set to get sixteen different method of calculating.

\section{EXPERIMENTAL}

Synthesis of methyl 2-[(2-oxo-2H-chromen-4-yl)oxy]acetate $^{24-27}$ : Gaussian 03, Revision C. $01^{28}$ used for calculation the ground-state geometry optimized to a local minimum, harmonic vibration frequency and studied the active vibration frequncy in infra red. Chosen four DFT models are given by combining the exchange and correlation functional and four basis set to get sixteen different method of calculating each method includes a single DFT model and a single basis set. These basis sets are (STO-3G, 6-31G, LanL2DZ ${ }^{29}$ and DGTZVP $^{30}$ ). Two of DFT models (B3LYP and B3PW91) are hybrid functionals. Three hybrid functionals, which include a mixture of Hartree-Fock exchange with DFT exchangecorrelation, B3 The becke three-parameter exchange functional $^{31}$. LYP the Lee-Yang-Parr correction functional ${ }^{32}$. PW91 (Perdew/Wang 91): Perdew and Wang's 1991 gradient-corrected correlation functional ${ }^{33}$. The other two DFT models are (MPW1PW91 and HCTH), MPW1 The Perdew-Wang 1991 exchange functional as modified by Adamo and Barone ${ }^{34}$. 
HCTH Handy's family functional including gradient-corrected correlation $^{35}$. HCTH refers to HCTH/407.

\section{RESULTS AND DISCUSSION}

The synthesized molecule has never been studied theoretically. Methyl 2-[(2-oxo-2H-chromen-4-yl)oxy]acetate molecule has 84 vibration modes, 72 modes are effectively in IR spectrum was a choice of six is (stretching vibration for ( $\mathrm{C}-\mathrm{H}$, aromatic) bond, stretching vibration for $(\mathrm{C}-\mathrm{H}$, aliphatic) bond, stretching vibration for $(\mathrm{C}=\mathrm{O}$, ester $)$ bond, stretching vibration for $(\mathrm{C}=\mathrm{O}$, lactone) bond, stretching vibration for $(\mathrm{C}=\mathrm{C}$, alkene $)$ bond, stretching vibration for $(\mathrm{C}=\mathrm{C}$, aromatic $)$ bond. To choose the optimal computational method to calculate the frequencies of vibration theory by comparing the calculation results of the theoretical with the experimental results of measurement for each frequency of the six selected frequency modes.

Frequency of stretching vibration for $(\mathbf{C}-\mathbf{H})$ bond: The stretching vibrations of aromatic ring for coumarin derivatives occur in the region $3100-3025 \mathrm{~cm}^{-1}$ for asymmetric stretching. This permits the ready identification of the structure. However, heterocyclic compound vibration absorption bands are usually weak to be detected. In the present work, the band observed at $3089.5 \mathrm{~cm}^{-1}$ in the FT-IR spectrum of the synthesized coumarin derivative is assigned to asymmetric modes of vibrations. The B3LYP level at DGTZVP gives the wavenumber values at $\mathbf{3 1 9 3 . 2 8} \mathbf{~ c m}^{-1}$ for stretching vibrations (Table-1). In general, the aromatic stretching vibrations calculated theoretically are in good agreement with the experimental values for benzene ring. Tables 1 and 2 showed that the method of calculation (HCTH/DGTZVP) to calculate the stretching vibration for ( $\mathrm{C}-\mathrm{H}$, bond) aromatic and aliphatic calculation method optimal for this type of frequencies where the percentage error $(+03.35 \%)$ for stretching vibration for $(\mathrm{C}-\mathrm{H}$, aromatic) bond and $(+01.35 \%)$ for stretching vibration for (C-H, aliphatic) bond, but the job of time the central processing unit (cpu) for this method is: $4 \mathrm{~h} 15 \mathrm{~min}$ and $35 \mathrm{~s}$. This time is longer than the other methods as shown in the Table-3.

\begin{tabular}{|c|c|c|c|c|}
\hline \multicolumn{5}{|c|}{$\begin{array}{c}\text { CALCULATION RESULTS OF FREQUENCY OF STRETCHING } \\
\text { VIBRATION FOR (C-H, AROMATIC) TO SIXTEEN } \\
\text { METHODS OF CALCULATION }\end{array}$} \\
\hline \multicolumn{5}{|c|}{$3089.5 \mathrm{~cm}^{-1}$ (C-H, aromatic) } \\
\hline \multicolumn{5}{|c|}{ Density Function Theory (DFT) } \\
\hline Basis set & B3LYP & B3PW91 & MPW1PW91 & HCTH \\
\hline STO-3G & 3484.47 & 3494.68 & 3521.27 & 3442.98 \\
\hline $6-31 \mathrm{G}$ & 3224.90 & 3237.03 & 3256.94 & 3214.58 \\
\hline LanL2DZ & 3225.18 & 3242.86 & 3286.40 & 3214.87 \\
\hline DGTZVP & 3211.04 & 3224.42 & 3244.80 & 3193.28 \\
\hline
\end{tabular}

Frequency of stretching vibration for $(\mathrm{C}=\mathrm{O})$ bond: There are two types of this frequency are stretching vibration for $(\mathrm{C}=\mathrm{O}$, ester $)$ bond and stretching vibration for $(\mathrm{C}=\mathrm{O}$, lac tone) bond, results gave the method of calculating optimal each described in Tables 4 and 5. The results show that the method (MPW1PW91/LanL2DZ) are given the lowest percentage error is $(+0.03 \%)$ to calculate the frequency of stretching vibration for $(\mathrm{C}=\mathrm{O}$, ester) bond, while the method ( $\mathrm{HCTH} /$ LanL2DZ) is optimized to calculate the frequency of stretching vibration for $(\mathrm{C}=\mathrm{O}$, lactone $)$ bond because the percentage of
TABLE-2

CALCULATION RESULTS OF FREQUENCY OF STRETCHING VIBRATION FOR (C-H, ALIPHATIC) TO SIXTEEN METHODS OF CALCULATION

\begin{tabular}{|c|c|c|c|c|}
\hline \multicolumn{5}{|c|}{$2987.3 \mathrm{~cm}^{-1}$ (C-H, aliphatic) } \\
\hline \multicolumn{5}{|c|}{ Density Function Theory (DFT) } \\
\hline Basis set & B3LYP & B3PW91 & MPW1PW91 & HCTH \\
\hline STO-3G & 3262.69 & 3285.19 & 3313.11 & 3219.89 \\
\hline $6-31 G$ & 3053.86 & 3061.83 & 3080.41 & 3036.53 \\
\hline LanL2DZ & 3057.22 & 3071.73 & 3091.10 & 3039.75 \\
\hline DGTZVP & 3048.72 & 3056.93 & 3076.66 & 3027.76 \\
\hline
\end{tabular}

TABLE-3

TIME IT TAKES TO CALCULATE TO SIXTEEN METHODS OF CALCULATION (HOURS: MINUTES: SECONDS)

\begin{tabular}{lrclr}
\hline \multicolumn{5}{c}{ Time } \\
\hline \multicolumn{5}{c}{ Density Function Theory (DFT) } \\
\hline Basis set & B3LYP & B3PW91 & MPW1PW91 & HCTH \\
STO-3G & $00: 10: 55$ & $00: 10: 57$ & $00: 11: 04$ & $00: 17: 00$ \\
6-31G & $00: 39: 18$ & $00: 39: 56$ & $00: 39: 55$ & $00: 57: 33$ \\
LanL2DZ & $00: 45: 46$ & $00: 46: 05$ & $00: 46: 22$ & $01: 10: 09$ \\
DGTZVP & $02: 29: 11$ & $02: 30: 55$ & $02: 31: 42$ & $04: 15: 35$ \\
\hline
\end{tabular}

TABLE-4

CALCULATION RESULTS OF FREQUENCY OF STRETCHING VIBRATION FOR (C=O, ESTER) TO SIXTEEN METHODS OF CALCULATION

\begin{tabular}{ccccr}
\hline \multicolumn{5}{c}{$1759.3 \mathrm{~cm}^{-1}(\mathrm{C}=\mathrm{O}$, ester $)$} \\
\hline \multicolumn{5}{c}{ Density Function Theory (DFT) } \\
\hline Basis set & B3LYP & B3PW91 & MPW1PW91 & HCTH \\
STO-3G & 1871.20 & 1899.78 & 1921.89 & 1864.45 \\
6-31G & 1755.05 & 1773.22 & 1791.12 & 1738.60 \\
LanL2DZ & 1722.50 & 1742.10 & 1759.90 & 1707.80 \\
DGTZVP & 1828.83 & 1852.21 & 1871.92 & 1817.95 \\
\hline
\end{tabular}

\begin{tabular}{lcccc} 
TABLE-5 \\
RESULTS CALCULATION OF FREQUENCY OF \\
STRETCHING VIBRATION FOR (C=O, LACTONE) TO \\
SIXTEEN METHODS OF CALCULATION \\
\hline \multicolumn{5}{c}{$1717.6 \mathrm{~cm}^{-1}$ (C=O, lactone) } \\
\hline \multicolumn{5}{c}{ Density Function Theory (DFT) } \\
\hline Basis set & B3LYP & B3PW91 & MPW1PW91 & HCTH \\
STO-3G & 1835.40 & 1861.73 & 1881.67 & 1840.12 \\
6-31G & 1761.24 & 1777.18 & 1793.33 & 1754.50 \\
LanL2DZ & 1722.00 & 1740.42 & 1756.37 & 1718.18 \\
DGTZVP & 1801.53 & 1822.91 & 1841.50 & 1795.10 \\
\hline
\end{tabular}

error least is $(+0.03 \%)$, but the job of time the central processing unit (cpu) for method (HCTH/LanL2DZ) is more time calculation for method (MPW1PW91/LanL2DZ) is: $23 \mathrm{~min}$ and $47 \mathrm{~s}$, as shown in the Table-3.

Frequency of stretching vibration for $(\mathrm{C}=\mathrm{C})$ bond: Tables 6 and 7 showed that the method of calculation (B3LYP/ DGTZVP) to calculate the frequency of stretching vibration for $(\mathrm{C}=\mathrm{C}$, bond $)$ alkene and aromatic calculation method optimal for this type of frequencies where the percentage error $(+03.35 \%)$ for stretching vibration for $(\mathrm{C}=\mathrm{C}$, alkene $)$ bond and $(+01.35)$ for stretching vibration for $(\mathrm{C}=\mathrm{C}$, aromatic $)$ bond and the job of time the central processing unit (cpu) for this method is: $2 \mathrm{~h} 29 \mathrm{~min}$ and $11 \mathrm{~s}$. This time is longer as shown in the Table- 3 .

Stable form of the molecule calculated and electronic distribution of the high occupied molecular orbital (HOMO) 


\begin{tabular}{|c|c|c|c|c|}
\hline \multicolumn{5}{|c|}{$\begin{array}{c}\text { TABLE-6 } \\
\text { CALCULATION RESULTS OF FREQUENCY OF } \\
\text { STRETCHING VIBRATION FOR (C=C, ALKENE) } \\
\text { TO SIXTEEN METHODS OF CALCULATION }\end{array}$} \\
\hline \multicolumn{5}{|c|}{$1629.2 \mathrm{~cm}^{-1}(\mathrm{C}=\mathrm{C}$, alkene $)$} \\
\hline \multicolumn{5}{|c|}{ Density Function Theory (DFT) } \\
\hline Basis set & B3LYP & B3PW91 & MPW1PW91 & HCTH \\
\hline STO-3G & 1744.09 & 1768.13 & 1790.35 & 1730.90 \\
\hline $6-31 \mathrm{G}$ & 1675.34 & 1690.80 & 1707.81 & 1659.99 \\
\hline LanL2DZ & 1666.04 & 1684.34 & 1701.20 & 1656.73 \\
\hline DGTZVP & 1654.15 & 1687.99 & 1705.29 & 1655.02 \\
\hline \multicolumn{5}{|c|}{$\begin{array}{l}\text { CALCULATION RESULTS OF FREQUENCY OF } \\
\text { STRETCHING VIBRATION FOR (C=C, AROMATIC) } \\
\text { TO SIXTEEN METHODS OF CALCULATION }\end{array}$} \\
\hline \multicolumn{5}{|c|}{$1577.6 \mathrm{~cm}^{-1}(\mathrm{C}=\mathrm{C}$, aromatic $)$} \\
\hline \multicolumn{5}{|c|}{ Density Function Theory (DFT) } \\
\hline Basis set & B3LYP & B3PW91 & MPW1PW91 & HCTH \\
\hline STO-3G & 1725.73 & 1747.76 & 1767.68 & 1709.70 \\
\hline 6-31G & 1658.01 & 1670.91 & 1686.82 & 1639.85 \\
\hline LanL2DZ & 1641.07 & 1657.79 & 1674.13 & 1627.99 \\
\hline DGTZVP & 1608.53 & 1670.13 & 1685.80 & 1640.92 \\
\hline
\end{tabular}

and the low unoccupied molecular orbital (LUMO) calculated in Fig.1.

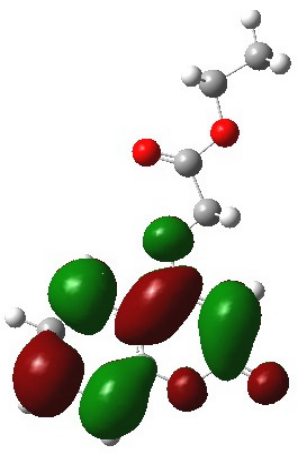

Methyl 2-[(2-oxo-2H-chromen -4-yl)oxy]acetate

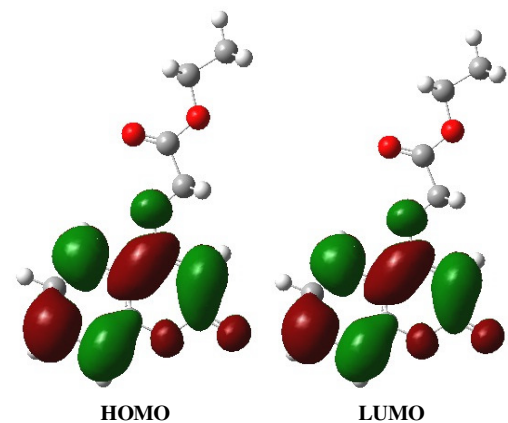

HOMO

LUMO
Fig. 1. Stable form of Methyl 2-[(2-oxo-2H-chromen-4-yl)oxy]acetate molecule calculated and (HOMO) and (LUMO)

\section{Conclusion}

In this study, methyl 2-[(2-oxo-2H-chromen-4-yl)oxy]acetate was synthesized and characterized using various spectroscopic methods and elemental analysis. The synthesized compound was studied theoretically and we finding the best method of calculation to six kinds of stretching vibration frequencies contained within the molecule methyl 2-[(2-oxo-2H-chromen4-yl)oxy]acetate. Chosen four DFT models are given by combining the exchange and correlation functional and four basis set to get sixteen different method of calculating. Found that the best method of calculation to Frequency of stretching vibration for $(\mathrm{C}-\mathrm{H})$ bond is (HCTH/DGTZVP), for frequency of stretching vibration for $(\mathrm{C}=\mathrm{O}$, ester) bond is (MPW1PW91/ LanL2DZ), for frequency of stretching vibration for $(\mathrm{C}=\mathrm{O}$, lactone) bond is (HCTH/LanL2DZ), for frequency of stretching vibration for $(\mathrm{C}=\mathrm{C})$ bond is $(\mathrm{B} 3 \mathrm{LYP} / \mathrm{DGTZVP})$.

\section{REFERENCES}

1. J. Li, X.G. Li and S.R. Wang, Spectrochim. Acta A, 88, 31 (2012).

2. S. Parmar and R. Kumar, J. Med. Chem., 11, 635 (1968).

3. Y.D. Reddy and V.V. Somayajulu, J. Indian Chem. Soc., 58, 599 (1981).

4. T.O. Soine, J. Pharm. Sci., 53, 231 (1964).

5. L. Jurd, J. Corse, A.D. King Jr., H. Bayne and K. Mihara, Phytochemicals, 10, 2971 (1971).

6. O.A. Abd Allah, II Farmaco, 55, 641 (2000).

7. E.H. Abdel-Al, M.I. Al-Ashamawi and B. Abd El-Fattah, Die Pharm., 38, 833 (1983).

8. R.P. Bhamaria, R.A. Bellare and C.V. Deliwala, Indian J. Exp. Biol., 6, 62 (1968).

9. M.M. Dutta, B.N. Goswani and J.C.S. Kataky, J. Heterocycl. Chem., 23, 793 (1986).

10. A.K.S. Gupta, M. Garg and U. Chandra, J. Indian Chem. Soc., 56, 1230 (1979).

11. W. Wenner, J. Org. Chem., 18, 1333 (1953).

12. A.K. Mansour, M.M. Eid and N. Khalil, Molecules, 8, 744 (2003).

13. J.R.S. Hoult and M. Paya, Gen. Pharmacol., 27, 713 (1996).

14. K.C. Fylaktakidou, D.J. Hadjipavlou-Litina, K.E. Litinas and D.N. Nicolaides, Curr. Pharm. Des., 10, 3813 (2004).

15. T. Yu, Y. Zhao and D. Fan, J. Mol. Struct., 791, 18 (2006).

16. T.Z. Yu, Y.L. Zhao, X.S. Ding, D.W. Fan, L. Qian and W.K. Dong, J. Photochem. Photobiol. A, 188, 245 (2007).

17. D. Ray and P.K. Bharadwaj, Inorg. Chem., 47, 2252 (2008).

18. S.R. Trenor, A.R. Shultz, B.J. Love and T.E. Long, Chem. Rev., 104, 3059 (2004).

19. Y. Tianzhi, Z. Peng, Z. Yuling, Z. Hui, M. Jing and F. Duowang, Spectrochim. Acta A, 73, 168 (2009).

20. C. Ruikui, Y. Xichuan, T. Haining and S. Licheng, J. Photochem. Photobiol. A, 189, 295 (2007).

21. T.Z. Yu, P. Zhang, Y.L. Zhao, H. Zhang, J. Meng, D.W. Fan and W.K. Dong, J. Phys. D: Appl. Phys., 41, 235406 (2008).

22. C.W. Tang and S.A. VanSlyke, Appl. Phys. Lett., 51, 913 (1987)

23. D. Sajan, Y. Erdogdu, R. Reshmy, Ö. Dereli, K.K. Thomas and I.H. Joe, Spectrochim. Acta A, 82, 118 (2011).

24. A.A. Al-Amiery, A.Y. Musa, A.A.H. Kadhum and A. Mohamad, Molecules, 16, 6833 (2011).

25. A.A. Al-Amiery, A.Y. Musa, A.A.H. Kadhum and A. Mohamad, Int. J. Mol. Sci., 12, 5757 (2011).

26. A.A.H. Kadhum, A.A. Al-Amiery, M. Shikara, A. Mohamad and R. Al-Bayati, Int. J. Phys. Sci., 6, 6692 (2012).

27. A.A. Al-Amiery, A.A.H. Kadhum and A. Mohamad, Molecules, 17, 5713 (2012).

28. M.J. Frisch, G.W. Trucks, H.B. Schlegel, G.E. Scuseria, M.A. Robb, J.R. Cheeseman, J.A. Montgomery, Jr., T. Vreven, K.N. Kudin, J.C. Burant, J.M. Millam, S.S. Iyengar, J. Tomasi, V. Barone, B. Mennucci, M. Cossi, G. Scalmani, N. Rega, G.A. Petersson, H. Nakatsuji, M. Hada, M. Ehara, K. Toyota, R. Fukuda, J. Hasegawa, M. Ishida, T. Nakajima, Y. Honda, O. Kitao, H. Nakai, M. Klene, X. Li, J.E. Knox, H.P. Hratchian, J.B. Cross, V. Bakken, C. Adamo, J. Jaramillo, R. Gomperts, R.E. Stratmann, O. Yazyev, A.J. Austin, R. Cammi, C. Pomelli, J. W. Ochterski, P.Y. Ayala, K. Morokuma, G A. Voth, P. Salvador, J.J. Dannenberg, V.G. Zakrzewski, S. Dapprich, A.D. Daniels, M.C. Strain, O. Farkas, D.K. Malick, A.D. Rabuck, K. Raghavachari, J.B. Foresman, J.V. Ortiz, Q. Cui, A.G. Baboul, S. Clifford, J. Cioslowski, B.B. Stefanov, G. Liu, A. Liashenko, P. Piskorz, I. Komaromi, R.L. Martin, D.J. Fox, T. Keith, M.A. Al-Laham, C.Y. Peng, A. Nanayakkara, M. Challacombe, P.M.W. Gill, B. Johnson, W. Chen, M.W. Wong, C. Gonzalez and J. A. Pople, Gaussian, Inc., Wallingford CT, 2004 Gaussian 03W (Revision C.01), Gaussian, Inc., Wallingford CT (2003).

29. V.A. Rassolov, M.A. Ratner, J.A. Pople, P.C. Redfern and L.A.J. Curtiss, Comp. Chem., 22, 976 (2001).

30. C. Sosa, J. Andzelm, B.C. Elkin, E. Wimmer, K.D. Dobbs and D.A.J. Dixon, Phys. Chem., 96, 6630 (1992).

31. A.D. Becke, J. Chem. Phys., 98, 5648 (1993).

32. C. Lee, W. Yang and R.G. Parr, Phys. Rev., B37, 785 (1988).

33. J.P. Perdew, K. Burke and Y. Wang, Phys. Rev., B54, 16533 (1996).

34. C. Adamo and V. Barone, J. Chem. Phys., 108, 664 (1998).

35. A.D. Boese and N.C. Handy, J. Chem. Phys., 114, 5497 (2001). 